\title{
Pathological changes in juvenile Atlantic halibut Hippoglossus hippoglossus persistently infected with nodavirus
}

\author{
R. Johansen ${ }^{1, *}$, T. Ranheim ${ }^{1}$, M. K. Hansen ${ }^{2}$, T. Taksdal ${ }^{1}$, G. K. Totland ${ }^{3}$ \\ ${ }^{1}$ National Veterinary Institute, PO Box 8156 Dep., 0033 Oslo, Norway \\ ${ }^{2}$ Norwegian School of Veterinary Science, PO Box 8146 Dep., 0033 Oslo, Norway \\ ${ }^{3}$ University of Bergen, Department of Zoology, Allegt. 41, 5007 Bergen, Norway
}

\begin{abstract}
This is the first description of a persistent subclinical nodavirus infection in the Atlantic halibut Hippoglossus hippoglossus. Juvenile fish (1 to $5 \mathrm{~g}$ ) were sampled at 4, 5 and 8 mo of age at a fish farm in Norway during and after weaning. None showed clinical signs of viral encephalopathy and retinopathy (VER) or other disease. Pathological changes and/or nodavirus were detected by light microscopy, immunohistochemistry, reverse transcriptase polymerase chain reaction (RT-PCR) and transmission electron microscopy in all fish examined. High numbers of virus particles were found in macrophage-like cells in the central nervous system, including brain and retina (CNS). The virus particles displayed the icosahedral shape and size (approximately $25 \mathrm{~nm}$ ) characteristic of nodaviruses. The virus-infected cells formed focal cell aggregates and were seen in all regions of the brain and all nuclear cell layers of the retina. The cytoplasm of the infected cells was filled with membraneenclosed inclusions packed with virus particles. Some virus particles lay along membranes and formed membrane-bound necklace-like arrangements. The virus-infected cells of the retina also contained pigment granula located generally inside virus inclusions and sometimes forming a coating around the virus particles. All frontal parts with the eyes and brain and $50 \%$ of the mid-parts, which included the abdominal organs, were found positive for nodavirus with RT-PCR. Pathological changes in these persistently nodavirus-infected fish differ from earlier descriptions in Atlantic halibut during outbreaks of VER. Vertical transmission from infected spawners is believed to be a major route for nodavirus infection. Detection of nodavirus in subclinical infected fish and a better understanding of its pathogenesis are important in order to prevent the spread of nodavirus in the fish-farming industry.
\end{abstract}

KEY WORDS: Atlantic halibut - Fish - Nodavirus - Persistent infection - Subclinical infection · Immunohistochemistry $\cdot$ Ultrastructure $\cdot$ Viral encephalopathy and retinopathy $\cdot$ VER

\section{INTRODUCTION}

Nodaviruses are small (25 to $30 \mathrm{~nm}$ ), non-enveloped, icosahedrally shaped, single-stranded RNA viruses which have been reported from more than 30 species of marine fish in many parts of the world. Nodaviruses cause viral encephalopathy and retinopathy (VER), also called viral nervous necrosis (VNN), which is a

*E-mail: renate.johansen@vetinst.no problem in the farming of several fish species (Munday \& Nakai 1997, Grotmol 2000). Grotmol et al. (1995) first described nodavirus infection in Atlantic halibut. Outbreaks of VER have since been diagnosed in several halibut farms in Norway, and VER is now one of the major problems in the halibut farming industry. Clinical signs of acute VER in juvenile fish include lack of appetite, changes in pigmentation, neurological signs such as abnormal swimming, and mortality rates up to $100 \%$. Histopathological changes during the acute stage are degeneration and vacuolation of cells in 
brain and retina, and nodavirus-like particles are revealed by transmission electron microscopy (TEM) (Grotmol et al. 1997).

Nodaviruses in marine fishes are believed to be transferred from infected spawners to their offspring during spawning (Grotmol \& Totland 2000). Nodavirus has been detected in gonads of striped jack Pseudocaranx dentex spawners by a reverse transcriptase polymerase chain reaction (RT-PCR) technique (Arimoto et al. 1992, Mushiake et al. 1992). Selection of nodavirus-free spawners using enzyme-linked immunosorbent-assay (ELISA) for detection of antibodies and RT-PCR techniques have successfully reduced incidences of VER in juvenile sea bass Dicentrarchus labrax, striped jack and barfin flounder (Verasper moseri) (Arimoto et al. 1992, Mushiake et al. 1994, Breuil \& Romestand 1999, Breuil et al. 2000, Watanabe et al. 2000). The tissue distribution of nodavirus in subclinically infected adult striped jack has been investigated using a fluorescent antibody technique (FAT; Nguyen et al. 1997). Immune positive cells were found in the ovary, bile ducts, intestines and kidney tubuli. No positive cells were seen in the CNS, no pathological changes were discovered, and nodavirus was not detected by electron microscopy.

Nodavirus-infected eggs produce infection in newly hatched halibut larvae (Grotmol \& Totland 2000). Bath exposures to nodavirus have been reported to induce VER in larval and juvenile stage halibut, but not in larger halibut (Grotmol 2000). Knowledge of the pathogenesis of nodavirus infections is scarce. A better understanding of subclinical and persistent infections of nodavirus is important in order to detect and prevent nodavirus infections in fish farms.

The aim of this study was to reveal the pathogenesis of subclinical persistent nodavirus infections in Atlantic halibut. Light microscopy, immunohistochemistry (IHC), RT-PCR and TEM were used to determine the tissue distribution of virus-particles and histopathological changes. This is the first description of a subclinical persistent nodavirus infection in Atlantic halibut, and the first electron microscopic study of nodavirus in persistently infected fish.

\section{MATERIALS AND METHODS}

Fish sampling and rearing conditions. The fish were hatched in an intensive rearing system in a commercial Norwegian halibut farm. The farm had a previous record of VER but was believed to be nodavirus-free at the time of first sampling. Eggs were bought from another Norwegian halibut farm, also with a previous record of VER. Only enriched brine shrimp Artemia sp. were used as first feed. At 4 mo of age, the fish were weaned onto a commercial dry pelleted feed. The fish had not been graded and therefore varied considerably in size. Only the smallest fish (1 to $5 \mathrm{~g}$ ), located close to the water outlet of the raceways, were sampled. The first samples were taken at a routine inspection during weaning when the fish were about 4 mo of age. Only a few fish were sampled at this point, and these were fixed whole in phosphate-buffered $10 \%$ formalin. Since the first samples were positive for nodavirus, a new sampling was done at about 5 mo of age. The fish were transported live to the National Veterinary Institute in Oslo. On arrival, 20 fish were killed by an overdose of clorbutanol, and tissue samples were taken. Ten fish were transferred to $1 \mathrm{~m}^{3}$ fiberglass tanks and maintained in recirculating seawater at a temperature of $12^{\circ} \mathrm{C}$ and a salinity of $3.3 \%$ for a 3 mo observation period before sampling at $8 \mathrm{mo}$ of age.

Tissue preparation for light microscopy. Small fish (about $1 \mathrm{~g}$ ) were fixed whole. Larger fish were divided into 3 sections: a frontal part with brain, eyes and gills, a second part that included muscle, skin, kidney, spinal cord and ganglia, and a third part consisting of abdominal organs such as liver, intestines and spleen. Tissues were fixed for at least $24 \mathrm{~h}$ in neutral phosphatebuffered $10 \%$ formalin. Standard processing procedures for light microscopy (LM) were followed. After embedding in paraffin, 4 to $6 \mu \mathrm{m}$ sections were cut and stained with haematoxylin and eosin (H\&E).

Immunohistochemistry. Formalin-fixed and paraffinembedded organs for histopathological examination were also sectioned for immunohistochemistry. Nodavirus antigens were detected using a streptavidinbiotin-alkaline-phosphatase complex immunochemical technique. Sections were deparaffinized at $58^{\circ} \mathrm{C}$ for $25 \mathrm{~min}$, washed in xylene baths, rehydrated through an ethanol series, and brought to distilled water. Nonspecific antibody binding sites were blocked with $5 \%$ bovine serum albumin (BSA) in Tris-buffered saline (TBS, pH 7.4) for $20 \mathrm{~min}$. Between each step the slides were washed in TBS for at least $5 \mathrm{~min}$. The primary antiserum (rabbit) was raised against purified cell culture propagated nodavirus from Atlantic halibut (Johansen unpubl. data). The virus from Atlantic halibut was isolated and further propagated in a SSN-1 cell line (Dannevig et al. 2000). Sections were incubated with the antiserum (1:500 in $2.5 \% \mathrm{BSA}$ in TBS) for $30 \mathrm{~min}$. The secondary antibody, biotinylated goat anti-rabbit immunoglobulin (1:500 in $2.5 \%$ BSA in TBS), was added to the sections before incubation for $30 \mathrm{~min}$. Streptavidin-alkaline-phosphate complex 1:500 in $2.5 \%$ BSA in TBS was added for 30 min. Fast red was used as a substrate and was left on the slides for $20 \mathrm{~min}$. Slides were then counterstained with haematoxylin and cover glasses were mounted with Aquamount. 
The same procedure without primary antiserum was followed to make negative controls. Halibut tissue known to be infected with nodavirus was used as a positive control.

Tissue processing for TEM. Brain, retina and kidney were sampled from three 8 mo old fish and fixed for at least $24 \mathrm{~h}$ in a fixative consisting of $10 \mathrm{ml} 10 \%$ formaldehyde, $10 \mathrm{ml} 25 \%$ glutaraldehyde, $20 \mathrm{ml} 0.2 \mathrm{M}$ cacodylate buffer and $60 \mathrm{ml}$ PBS ( $\mathrm{pH}$ 7.4). Samples were then rinsed in buffer, postfixed in $1 \%$ osmium tetroxide, dehydrated in ethanol and embedded in LX112. Semi-thin sections ( 0.5 to $1 \mu \mathrm{m})$ stained with toluidine blue were studied under a light microscope in order to identify areas with focal clusters of macrophage-like cells. Ultra-thin sections (80 to $90 \mathrm{~nm}$ ) were contrasted in uranyl acetate and lead citrate and studied in a Philips 208S transmission electron microscope.

Tissue sampling and processing for RT-PCR. Tissue samples were collected from 10 fish and were excised from frontal (eyes and brain) and caudal (abdominal organs) parts, omitting the tail. Samples were immediately flash-frozen in liquid nitrogen and stored at $-80^{\circ} \mathrm{C}$. Frozen specimens were homogenized into powder with a pestle and mortar in liquid nitrogen before analysis. Total RNA was isolated from the frozen powder using RNeasy kit from Qiagen (Valencia, CA, USA) in accordance with the manufacturer's handbook.

Reverse transcription and DNA amplification were carried out in a single tube using GeneAmp EZ rTth RNA PCR kit from Perkin Elmer (Foster City, CA, USA), using $0.5 \mu \mathrm{g}$ total RNA, $0.5 \mu \mathrm{M}$ of the forward primer 5'-CTG-AAG-ATA-CAT-TCG-CTC-CAA-3' and $0.5 \mu \mathrm{M}$ of the reverse primer 5 '-TAT-CCC-ATA-GCCCCC-AGT-G-3'. Reverse transcription was initiated by denaturation at $94^{\circ} \mathrm{C}$ for $2 \mathrm{~min}$, followed by the reverse transcription step at $60^{\circ} \mathrm{C}$ for $30 \mathrm{~min}$. DNA amplification was performed using 30 cycles of a 2-temperature PCR $\left(94^{\circ} \mathrm{C}\right.$ for $45 \mathrm{~s}, 55^{\circ} \mathrm{C}$ for $\left.45 \mathrm{~s}\right)$ and ended at $60^{\circ} \mathrm{C}$ for $7 \mathrm{~min}$. All organic solutions were of reagent grade. The design of primers was based on the sequence of the RNA2 from Atlantic halibut nodavirus (Grotmol et al. 2000).

\section{RESULTS}

\section{Observations and mortality of fish}

No clinical signs of VER or other disease were observed at the fish farm or during the 3 mo observation period at the veterinary institute. In the fish farm, mortality rates were high at 3 distinct time points during first feeding and weaning (Fig. 1).

\section{Histopathology and immunohistochemistry}

All fish examined with immunohistochemistry were positive for nodavirus. Multifocal cell aggregates of macrophage-like cells were seen in all regions of the brain and all nuclear cell layers of the retina (Figs. 2 $\& 3)$. The cell aggregates were clearly confined and consisted of 3 to 50 large mononuclear cells as seen in the sections (Figs. 2b \& 3b). The cytoplasm of the macrophage-like cells stained intensely with either eosin or haematoxylin, and was amphophilic when both stains were used (Fig. 3). Some cells, particularly in the retina, contained dark pigment granula (not shown). The focal cell aggregates and some single cells in the brain and retina were immunopositive for nodavirus (Figs. $2 \& 4$ ).

There seemed to be no differences in the number and distribution of cell aggregates in fish from the 3 samplings. In brain tissue, most cell aggregates were found in the inner ventricular layers of the tectum opticum and close to growth zones of telencephalon and diencephalons (Fig. 2). In the retina, most of the large cell aggregates were seen in the inner nuclear cell layer (Fig. 3). In the pigment cell layer, cell aggregates, smaller pigment clusters and vacuoles were seen (Fig. 4). LM revealed little or no change in brain and retinal tissues around the cell aggregates. Vacuoles were seen in cells of the tectum opticum in only one 5 mo old fish. Some enlargement of intercellular spaces was visible in the inner nuclear cell layer and ganglion cell layer of the retina (Fig. 3).

No similar aggregates of macrophage-like cells were seen outside the brain and retina. Sections of liver from the first 2 samplings showed large numbers of multifocal, confined, rounded clusters of vacuolated cells (Fig. 5). The clusters ranged from 30 to $150 \mu \mathrm{m}$ in diameter. Cells in the clusters were completely filled with vacuoles ranging in size from 10 to $35 \mu \mathrm{m}$, and the nuclei were dislocated to the edge of the cells. These clusters seemed to disappear with time, since no clus- 


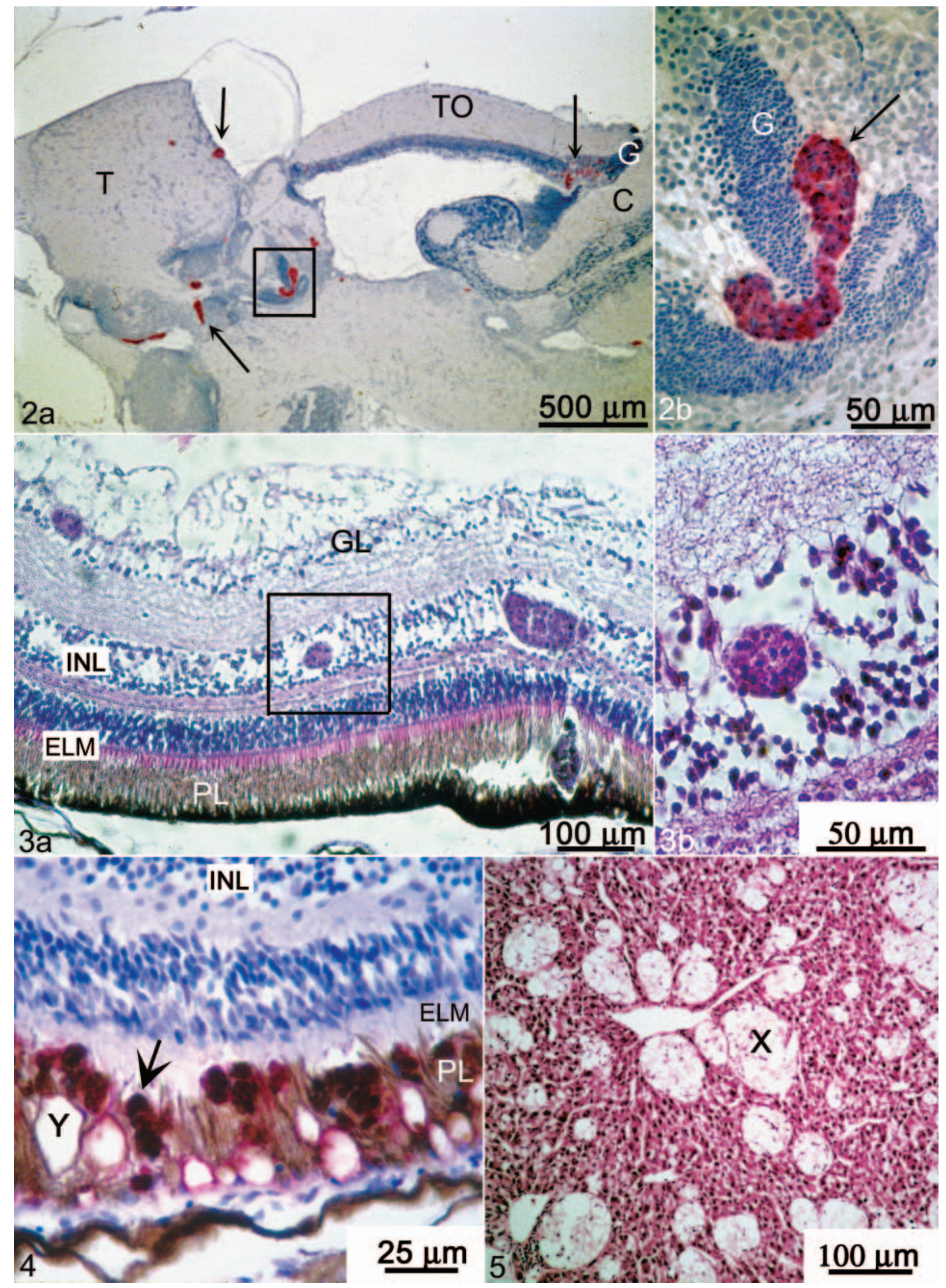


Figs. 2 to 5. Hippoglossus hippoglossus. Light microscopy observations in nodavirus-infected fish. Fig. 2. (a,b) Immunolabelled section of brain from a 5 mo old fish; aggregates (arrows) of immunolabelled cells (red) often appear close to growth zones (G); (b) shows a higher magnification of inset in (a); T: telencephalon; TO: tectum opticum; C: cerebellum. Fig. 3. (a,b) H\&E-stained section of retina from an 8 mo old fish; most cell aggregates were seen in the ganglion cell layer (GL) and inner nuclear cell layer (INL); cell aggregates and clusters of pigment granula were also visible in the pigment cell layer (PL); ELM: external limiting membrane; (b) shows higher magnification of inset in (a). Fig. 4. Immunolabelled retina section from a 5 mo old fish, showing pigment clusters (arrow) and vacuoles (Y) in the pigment cell layer (PL); INL: inner nuclear cell layer; ELM: external limiting membrane. Fig. 5. H\&E-stained liver section from a 5 mo old fish, showing large amounts of confined, rounded clusters of vacuolated cells (X)

ters were seen in the fish examined at the last sampling. Immunostaining of these clusters for nodavirus were negative.

\section{Electron microscopy}

The cell aggregates seen in LM were easily identified by electron microscopy because of large, multiple, electron-dense inclusions in the cytoplasm of most cells (Fig. 6). The cell aggregates were clearly confined but no alignment or organization of the cells was observed. The cells had large pale nuclei that showed only slight pathological change even when the cytoplasm was full of inclusions (Fig. 7). The size (about $12 \mu \mathrm{m}$ ) and shape (often oval) of the cells, together with the large nucleus and number of inclusions, indicated that the aggregated cells could be macrophages. Inclusions were membrane-bound and differed in size, shape and density (Fig. 8). Most inclusions contained large numbers of virus particles, icosahedral in shape and approximately $25 \mathrm{~nm}$ in size, which is characteristic of fish nodaviruses (Fig. 9). Some virus particles lay alongside membranes and at times formed membrane-bound necklace-like arrangements (Fig. 9).

Some of the virus-infected cells of the retina contained melanin-like granula, mostly within the virus inclusions (Fig. 6). The melanin-like granules occasionally formed a coat around virus particles within inclusions (Fig. 10). Similar linings of melanin-like granules were also seen in inclusions containing no distinct virus particles (Fig. 11). Residual bodies and other lipofuscin-like pigments were also seen in the affected areas of retina and brain.

Enlarged intercellular spaces were present in the inner nuclear layer and ganglion cell layer of the retina, and some of the cells around virus-infected cell aggregates showed degeneration and vacuolation. Virus-infected cells in the pigment cell layer of retina were visible both as confined clusters like those observed in the other retinal cell layers, and as single cells along with clusters of pigment granula (Fig. 12), vacuoles, residual bodies and degenerated ends of rods and cones.

\section{Virus detection by RT-PCR}

We developed a sensitive assay that allows precise and specific detection of the fish nodavirus observed in Atlantic halibut. We examined 10 frontal (eyes and brain) and dorsal (abdominal organs) parts at the second sampling when the fish were approximately 5 mo old. Following gel electrophoresis of the RT-PCR reaction, a distinct band of approximately $264 \mathrm{bp}$ was evident in all the frontal samples and in 5 of the dorsal samples.

\section{DISCUSSION}

This is the first description of a persistent and subclinical nodavirus infection in Atlantic halibut. We use the term 'persistent' infection to emphasise that all fish examined displayed pathological changes and positive immunohistochemistry for nodavirus during the $4 \mathrm{mo}$ of sampling. We also detected virus particles in tissue by electron microscopy and virus genes by RT-PCR. Large numbers of the nodavirus were found in distinct cell aggregates in the CNS (including the brain and retina) of fish showing no signs of disease. The pathological changes differ from findings described in Atlantic halibut during acute outbreaks of VER (Grotmol et al. 1997). Similar pathological findings have been reported in sea bass Dicentrarchus labrax $42 \mathrm{~d}$ after experimental nodavirus infection (Peducasse et al. 1999). In the sea bass, cell aggregates were seen only in the inner nuclear layer and ganglion cell layer of the retina, together with vacuoles and basophilic cells. Only a few vacuolated cells and no cell aggregates were observed in the brain of the sea bass. Experimental studies on Atlantic halibut have not revealed histopathological changes similar to those described in the present paper. Nodavirus exposure to small fish produces $100 \%$ mortality, and larger fish are not infected (Grotmol 2000). So far we have not been able to identify the right age of Atlantic halibut and/or nodavirus dose to experimentally produce persistent survivors.

High mortality during the first stages of halibut rearing (Fig. 1) is not unusual, and is generally believed to 


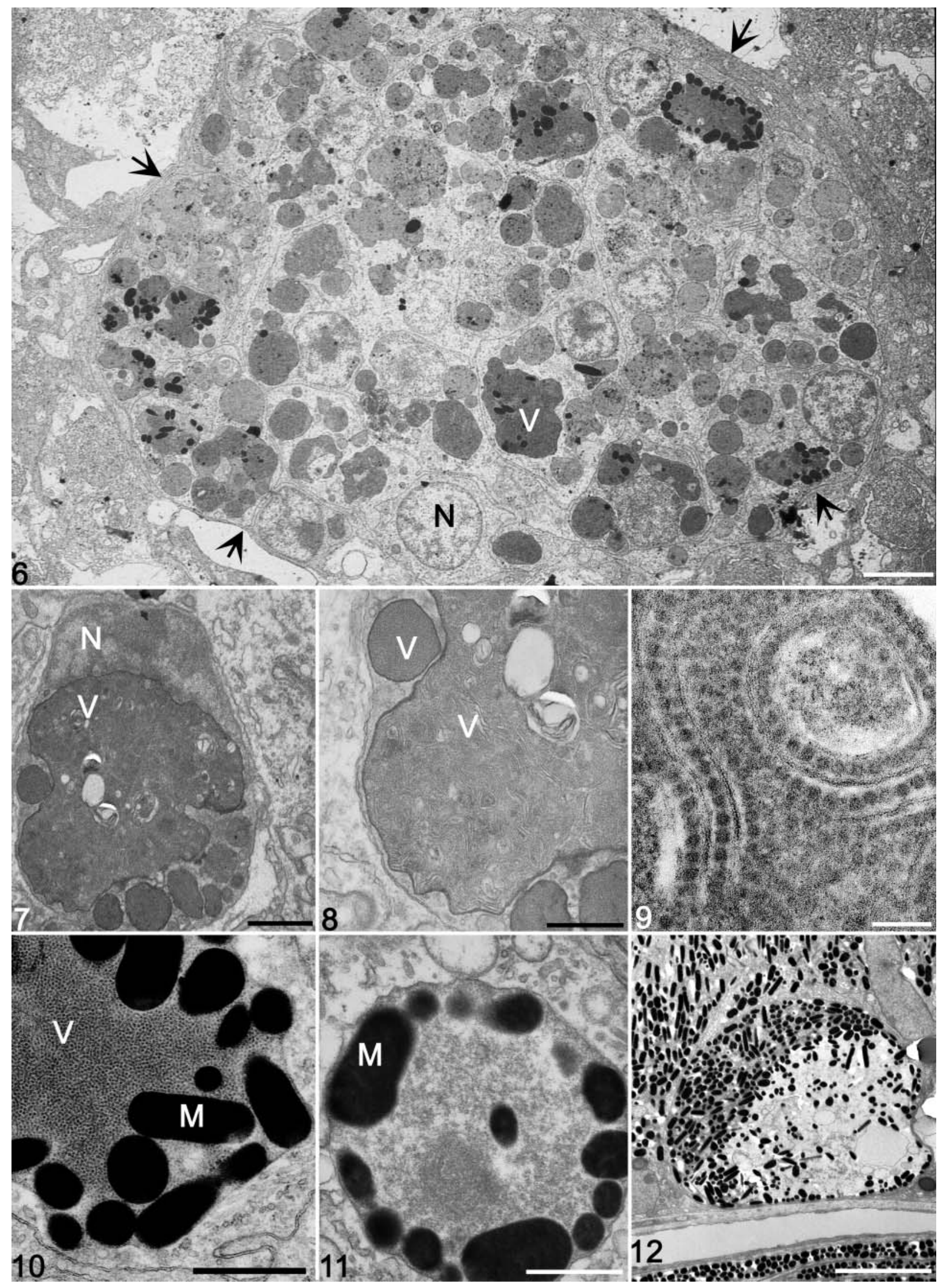


Figs. 6 to 12. Hippoglossus hippoglossus. Transmission electron microscope images from nodavirus-infected retina and brain of an 8 mo old fish. Fig. 6. Confined aggregate of macrophage-like cells in inner nuclear cell layer of retina; arrows indicate the edge of the cell aggregate; most cells had large rounded pale nuclei $(\mathrm{N})$; cytoplasm was filled with relatively electron-dense virus inclusions $(\mathrm{V})$; note that some inclusions also contained melanin-like granula; aggregated cells were positioned closely together, but no special organization of the cells inside or around the aggregates were registered (scale bar $=5 \mu \mathrm{m}$ ). Fig. 7 . Virus-infected cell in the brain; virus inclusions (V) totally fill the cytoplasm and push the nucleus $(\mathrm{N})$ to the edge of the cell (scale bar $=2 \mu \mathrm{m})$. Fig. 8. Small and large membrane-bound virus inclusions (V) in cytoplasm of a brain cell; note membrane-bound viruses forming

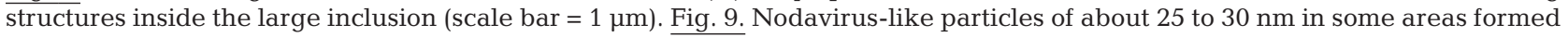
necklace-like arrangements along membranes (scale bar $=100 \mathrm{~nm}$ ). Fig. 10. Part of a virus inclusion, in a cell of the inner nuclear layer of the retina, with melanin-like granules (M) forming a coat around the virus-particles (V) (scale bar = $1 \mu \mathrm{m})$. Fig. 11 . Inclusion with a lining of melanin-like granules $(\mathrm{M})$, but without distinct virus-particles (scale bar $=1 \mu \mathrm{m}$ ). Fig. 12. Basal part of pigment cell layer of virus-infected retina with a large formation of pigment granula and vacuoles along Bruch's membrane $(\mathrm{scale}$ bar $=10 \mu \mathrm{m})$

be due to feeding and technical problems. At the farm investigated, the mortality rate during the yolk-sac stage (first $40 \mathrm{~d}$ ) was lower than $10 \%$, which was less than expected. At Day 40, the larvae were moved from the yolk-sac silos to start-feeding tanks. High mortality following transfer was expected and is not unusual. Currently it is common in halibut farming that a large percentage of fish do not start feeding, and that these larvae die between 60 and $80 \mathrm{~d}$ after hatching. Weaning is the next stage at which high mortality in juvenile halibut commonly occurs. The total percentage of survivors from hatching to weaning in this case was about $2.5 \%$. In modern halibut farming, a $10 \%$ survival rate is regarded as very good and $2.5 \%$ is not unusual. When the test results showed that all fish were infected with nodavirus, the farm management decided to slaughter all juvenile fish and begin again with eggs from a presumed nodavirus-free livestock. Further sampling was therefore not possible.

Outbreaks of nodavirus infection in Atlantic halibut are mostly seen during first feeding and weaning. The fish described in this paper were therefore within the accepted age range for nodavirus infection and disease outbreak. The time of infection of these fish is not known. The high rates of mortality during first feeding and weaning could hide an acute phase of nodavirus infection with subsequent development of a persistent subclinical phase.

Only 1 nodavirus strain has been reported in Atlantic halibut. Infections with other nodavirus strains could occur and give rise to a different mortality rate and pathogenesis. In sea bass, 2 different nodavirus strains have been detected from different parts of France (Thiery et al. 1999). Norwegian and Japanese scientists have challenged Atlantic halibut with nodavirus from striped jack, and vice versa (Totland et al. 1999). Neither fish were infected by the nodavirus from the other species. This shows that different species of fish have quite different degrees of susceptibility to individual strains of nodavirus. Differences in immune response and age might also explain differences in response to nodavirus challenge.
The close proximity of nodavirus-infected cell aggregates and growth zones (Fig. 2) might indicate that nodavirus favor neural cells in early stages of proliferation. Grotmol et al. (1999) showed that the whole brain, with the exception of growth zones, became immunopositive for nodavirus in experimentally infected Atlantic halibut larvae. It is likely that young fish have a higher proportion of CNS cells in the early proliferation stage than older fish. This could explain why young fish are more susceptible to severe nodavirus infections. Teleosts have the ability to produce new neurons even as adult fish, and this leads to continuous growth of the CNS throughout their lifetime (Zupanc \& Horschke 1995). Zones of high proliferative activity are typically located near the surface of the ventricular, paraventricular and cisternal systems (Zupanc 1999). Experimental studies of fish retina have shown almost $100 \%$ regeneration (Hitchcock \& Raymond 1992). This ability for CNS regeneration makes it possible for adult fish to show no sign of pathological change, even if severe changes were present at earlier stages. Two mechanisms of neurogenesis are known to give rise to retinal growth in fish: neurons can be produced in the marginal germinal zone, and rod precursor cells may give rise to rod photoreceptors. Retinal injury triggers the same 2 mechanisms and proliferating neurons are believed to migrate to the injured area (Cameron 2000). Clusters of proliferating 'neurogenic' cells are seen scattered across damaged retina (Raymond \& Hitchcock 2000). However, these clusters do not look like the virus-infected cell aggregates described in the present paper (Raymond pers. comm.).

Mononuclear phagocytes in the parenchyma of the CNS are either microglial cells or infiltrated haematogenic macrophages. Morphologically it is difficult to distinguish between activated microglial cells and haematogenic macrophages. Microglial cells are normally small resting cells that are activated to become large phagocytic cells during tissue damage. Microglial cells are mobile and can form clusters, known as microglial nodules, in humans (Kreutzberg et al. 1997). Breakdown of the blood-brain barrier under pathological 
conditions gives haematogenic cells access to the CNS. Clusters of activated macrophages are termed epithelioid granulomas (Burkitt et al. 1996). Granulomas usually have a surrounding zone of lymphocytes and the macrophages often further modify to form multinucleate giant cells, none of which were observed in our study. Neither of these terms is used in this study since the source of the aggregated cells was not established.

Melanomacrophages (MMP) are macrophages that contain pigment. Migrating MMP could explain the pigment granules seen in the virus-infected cells of the retina. In halibut, MMP are normally located in melanomacrophage centers in the kidney and spleen. MMP are known to be involved in defense mechanisms against various microbes (Roberts 1975, Agius 1985, Ferguson 1989). Roberts (1975) indicated that MMP migrate from hematopoietic tissue into blood vessels and then travel to infected tissue elsewhere in the fish. Retinal pigment epithelium (RPE) is another possible source of the melanin-like granules. There is no evidence of transdifferentiation of RPE into neural retina in fishes, but pigmented inclusions have been seen within repaired retina in experimental lesions (Raymond \& Hitchcock 2000). In the skin of mammals, melanin is known to be transferred from melanocytes to keratinocytes, but in RPE, melanin transport to other cells has not been reported (Garcia 1979).

Melanin-like granules seen in virus inclusions in the halibut retina might play an important role in the defense mechanism against nodavirus. The effects and origin of melanin in macrophages is a controversial subject. Some scientists believe that macrophages do not possess the cell machinery necessary for melanin synthesis and therefore have to engulf melanosomes or melanin from melanocytes (Zapata \& Chiba 1996). Melanin is a complex polymer that can absorb and neutralize free radicals, cations and other potentially toxic agents (Edelstein 1971). Edelstein (1971) indicated that melanin in leukocytes may have a bactericidal effect within the cell by oxidizing NADH and thereby generating hydrogen peroxide. Many articles and books refer to Edelstein's work, but new knowledge of the effects of melanin is scarce. One study showed that melanin inhibits the cytopathogenic effect (CPE) of HIV in cell cultures, but how melanin inhibits CPE was not studied (Sidibe 1996). The limited knowledge of the effects of melanin may arise from the fact that many scientists use albino rats in their research. Albino rats lack tyrosinase and are therefore unable to synthesize melanin. Further investigation of nodavirus infections might provide new knowledge of how melanin affects viruses within leukocytes.

In our study we observed differences between pathological changes on the inside and outside of the external limiting membrane formed from the scleral ends of the Müller cells (Figs. 3 \& 4). Recent experimental studies of Borna disease virus (BDV) in albino rats have brought new understanding of microglial cells, macrophages and the external limiting membrane (ELM; Kacza 2000). In the early stages of BDV infection, activated microglial cells migrate only through the retina on the inside of the ELM, while macrophages play a dominant role on the outside of the membrane. In later stages of BDV infection, microglial cells are also observed outside the ELM. Very few experimental animal models are available for the investigation of mechanisms involved in virus-induced damage within the CNS. Fishes are often used in experiments to study the general mechanisms of neurogenesis, and further study of nodavirus infections may reveal new aspects of CNS regeneration following virus infections in particular and neurogenesis in general.

Changes in the liver similar to those seen in our first 2 samplings have also been observed in nodavirus-infected halibut and turbot from other fish farms in Norway (Johansen unpubl. data). Similar changes have not been seen in nodavirus-free fish, but it is not known whether these changes are due to nodavirus infection or to other problems such as malnutrition or starvation (Fig. 5). The preparations of the liver material in the present study (e.g. paraffin-embedding) probably removed the contents from the vacuoles (e.g. fat or glycogen). Cryosections of frozen material would allow closer examination of the contents of the vacuoles.

This study has demonstrated that fish displaying no signs of disease over several months contained large numbers of nodavirus in cell aggregates in the CNS. Morphologically it is difficult to tell whether the fish or the virus are 'winning the battle', but there are many indications that in this case the fish are going into a carrier state. Pathological findings did not seem to change significantly during the 4 mo observation period, and the virus-infected cells appeared to be only slightly affected even when the cytoplasm was full of virus particles. Nodavirus is believed to spread from infected spawners to their offspring during the stress of spawning (Grotmol 2000). It is possible that the nodavirus remains in the fish from the juvenile stages until spawning. This study has shown that it is important to study the pathogenesis of nodavirus in persistently infected fish in order to control the spread of nodavirus and to enable us to select nodavirus-free spawners.

Acknowledgements. This project was funded by the Norwegian Research Council. Sincere thanks to Randi Terland, Else Engeland and Theresa Cieplinska for their skilled technical assistance. We are grateful to Dr. Bjørn Gjerde for the use of his photographic equipment and for his assistance with the photo-images. Thanks to Dr. Birgit Dannevig and Agnar Kvellestad for constructive criticism of the manuscript, and thanks to Duncan Colquhoun for correcting our English. 


\section{LITERATURE CITED}

Agius C (1985) The melano-macrophage centres of fish: a review. In: Manning MJ, Tatner MF (eds) Fish immunology. Academic Press, London, p 85-105

Arimoto M, Mushiake K, Mizuta Y, Nakai T, Muroga K, Furusawa I (1992) Detection of striped jack nervous necrosis virus (SJNNV) by enzyme-linked-immunosorbent-assay (ELISA). Fish Pathol 27:191-195

Breuil G, Romestand B (1999) A rapid ELISA method for detecting specific antibody level against nodavirus in the serum of the sea bass, Dicentrarchus labrax (L.): application to the screening of spawners in a sea bass hatchery. J Fish Dis 22:45 - 52

Breuil G, Pepin JF, Castric J, Fauvel C, Thiery R (2000) Detection of serum antibodies against nodavirus in wild and farmed adult sea bass: application to the screening of broodstock in sea bass hatcheries. Bull Eur Assoc Fish Pathol 20:95-100

Burkitt H, Stevens A, Lowe JS, Young B (1996) Chronic inflammation. In: Burkitt H, Stevens A, Lowe JS, Young B (eds) Wheather's basic histopathology: a colour atlas and text. Churchill Livingstone, New York, p 25-34

Cameron DA (2000) Cellular proliferation and neurogenesis in the injured retina of adult zebrafish. Vis Neurosci 17: 787-797

Dannevig BH, Nilsen R, Modahl I, Jankowska M, Taksdal T, Press CM (2000) Isolation in cell culture of nodavirus from farmed Atlanic halibut Hippoglossus hippoglossus in Norway. Dis Aquat Org 43:183-189

Edelstein LM (1971) Melanin: a unique biopolymer. In: Ioachim HL (ed) Pathobiology annual. Appeleton-CenturyCrofts, New York, p 309-324

Fenner F, Bachmann PA, Gibbs EPJ, Studdert MJ, White DO (1987) Veterinary virology. Academic Press, London

Ferguson HW (1989) Systemic pathology of fish. Iowa State University Press, Ames

Garcia RI (1979) Molecular and cell biology of melanin. In: Marmor MF, Zinn KM (eds) The retinal pigment epithelium. Harvard University Press, Cambridge, p 124-147

Grotmol S (2000) Nodavirus infections of farmed fish with emphasis on Atlantic halibut, Hippoglossus hippoglossus L. PhD thesis, University of Bergen

Grotmol S, Totland GK (2000) Surface disinfection of Atlantic halibut Hippoglossus hippoglossus eggs with ozonated sea-water inactivates nodavirus and increases survival of the larvae. Dis Aquat Org 39:89-96

Grotmol S, Totland GK, Kvellestad A, Fjell K, Olsen AB (1995) Mass mortality of larval and juvenile hatchery-reared halibut associated with the presence of virus-like particles in vacuolated lesions in the central nervous system and retina. Bull Eur Assoc Fish Pathol 15:176-180

Grotmol S, Totland GK, Thorud K, Hjeltnes BK (1997) Vacuolating encephalopathy and retinopathy associated with a nodavirus-like agent: a probable cause of mass mortality of cultured larval and juvenile Atlantic halibut Hippoglossus hippoglossus. Dis Aquat Org 29:85-97

Grotmol S, Bergh O, Totland GK (1999) Transmission of viral encephalopathy and retinopathy (VER) to yolk-sac larvae of the Atlantic halibut Hippoglossus hippoglossus: occurrence of nodavirus in various organs and a possible route of infection. Dis Aquat Org 36:95-106

Editorial responsibility: Jo-Ann Leong,

Corvallis, Oregon, USA
Grotmol S, Nerland AH, Biering E, Totland GK, Nishizawa T (2000) Characterisation of the capsid protein gene from a nodavirus strain affecting the Atlantic halibut Hippoglossus hippoglossus and design of an optimal reverse-transcriptase polymerase chain reaction (RT-PCR) detection assay. Dis Aquat Org 39:79-88

Hitchcock PF, Raymond PA (1992) Retinal regeneration. Trends Neurosci 15:103-108

Kacza J (2000) Neuron-glia interactions in the rat retina infected by Borna disease virus. Arch Virol 145:127-147

Kreutzberg GW, Blakemore F, Graeber MB (1997) Cellular pathology of the central nervous system. In: Graham DI, Lantos PL (eds) Greenfield's neuropathology. Edward Arnold, London, p 85-125

Munday BL, Nakai T (1997) Nodaviruses as pathogens in larval and juvenile marine finfish. World $\mathrm{J}$ Microbiol Biotechnol 13:375-381

Mushiake K, Arimoto M, Furusawa I, Nakai T, Muroga K (1992) Detection of antibodies against striped jack necrosis virus (SJNNV) from brood stocks of striped jack. Nippon Suisan Gakkaishi 58:2351-2356

Mushiake K, Nishizawa T, Nakai T, Furusawa I, Muroga K (1994) Control of VNN in striped jack-selection of spawners based on the detection of SJNNV gene by polymerase chain-reaction (PCR). Fish Pathol 29:177-182

Nguyen HD, Mushiake K, Nakai T, Muroga K (1997) Tissue distribution of striped jack nervous necrosis virus (SJNNV) in adult striped jack. Dis Aquat Org 28:87-91

Peducasse S, Castric J, Thiery R, Jeffroy J, LeVen A, Laurencin FB (1999) Comparative study of viral encephalopathy and retinopathy in juvenile sea bass Dicentrarchus labrax infected in different ways. Dis Aquat Org 36:11-20

Raymond PA, Hitchcock PF (2000) How the neural retina regenerates. In: Fini ME (ed) Vertebrate eye development. Springer-Verlag, Berlin, p 197-218

Roberts RJ (1975) Melanin-containing cells of teleost fish and their relation to disease. In: Ribelin WE, Migaki G (eds) The pathology of fishes. University of Wisconsin Press, Madison, WI, p 399-420

Sidibe S (1996) Effects of serotonin and melanin on in vitro HIV-1 infection. J Biol Regul Homeost Agents 10:19-24

Thiery R, Arnauld C, Delsert C (1999) Two isolates of sea bass, Dicentrarchus labrax L., nervous necrosis virus with distinct genomes. J Fish Dis 22:201-207

Totland GK, Grotmol S, Morita Y, Nishioka T, Nakai T (1999) Pathogenicity of nodavirus strains from striped jack Pseudocaranx dentex and Atlantic halibut Hippoglossus hippoglossus, studied by waterborne challenge of yolk-sac larvae of both teleost species. Dis Aquat Org 38:169-175

Watanabe K, Nishizawa T, Yoshimizu M (2000) Selection of brood stock candidates of barfin flounder using an ELISA system with recombinant protein of barfin flounder nervous necrosis virus. Dis Aquat Org 41:219-223

Zapata AG, Chiba A (1996) Cells and tissues of the immune system of fish. In: Iwama G, Nakanishi $T$ (eds) The fish immune system. Academic Press, San Diego, p 1-62

Zupanc GKH (1999) Neurogenesis, cell death and regeneration in the adult gymnotiform brain. J Exp Biol 202: $1435-1446$

Zupanc GKH, Horschke I (1995) Proliferation zones in the brain of adult gymnotiform fish: a quantitative mapping study. J Comp Neurol 353:213-233

Submitted: July 1, 2002; Accepted: February 17, 2002

Proofs received from author(s): 